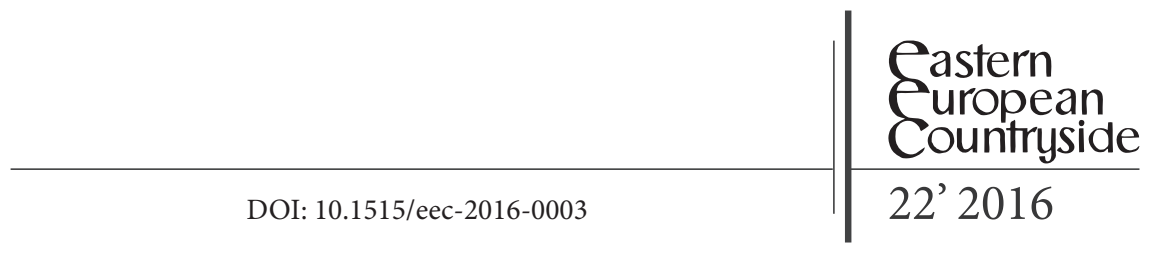

Martin Šimon, Josef Bernard

Local and Regional Studies, Institute of Sociology, Czech Academy of Sciences

\title{
Rural Idyll Without Rural Sociology? Changing Features, Functions and Research of the Czech Countryside ${ }^{*}$
}

\begin{abstract}
The development of the Czech countryside differs in many ways from trajectories typical for Eastern and Central European rural areas in the last 25 years. In our article, we discuss the nature of the 'Czech exceptionalism', with reference to three examples, namely population development, the dynamics of rural/agricultural labour markets and rural governance. Firstly, we describe the major driving forces behind rural development in Czechia over the past 25 years and how these forces are reflected in the academic discourse. Secondly, we argue that an important feature of rural regions in Czechia is their population growth combined with a rapid labour market transformation and a low social importance of agriculture. All these changes are interpreted as a shift towards multifunctionality of rural areas rather than as a general trend towards post-productivism; indeed, this is because large parts of rural areas remain economically based on industrial production. The ongoing transformations have been reflected only partially in an academic discourse. In conclusion, we argue that there is a need to re-examine the use of EEC as a concept framing the position of sociology in rural research.
\end{abstract}

Keywords: rural areas, rural idyll, Czechia, polarisation, agriculture, demographic change, global countryside

This article is based on research funded by the Czech Science Foundation ('The Socio-Spatial Disadvantage of Inhabitants in Peripheral Rural Regions', grant no. 15-10602S). 


\section{Introduction}

The countryside of East European countries has often been described as a territory with high levels of agricultural employment, dominated by small farms and peasants, with infrastructural deficiencies, and an ageing and decreasing population due to outmigration; it is also still inhabited by traditional communities, etc. (Ray and Bachvarov 1998; Swain 2000).

Moreover, many studies have argued that one of the manifestations stemming from rising social inequalities during the post-communist transformation is the growing economic gap between urban and rural areas in Central and Eastern Europe (Baum, Weingarten 2004) as well as rising social disadvantage in rural areas compared with their urban counterparts (Brown and Shafft 2003). Generally speaking, the outcome of post-communist transformation for rural areas in Central and Eastern Europe (CEE) is often described in terms of limited opportunity structures (Tickamyer and Duncan 1990) or material and opportunity deprivation (Cloke et al. 1995)1.

Although it is an apt description for many regions, it might be simultaneously argued that such a broad simplification obscures more than elucidates the contemporary rural change. Different polarisation and peripheralisation processes, as well as unequal engagement in globalisation trends have diversified the countryside of East Central Europe (ECE) over the last 25 years. Divergent paths of rural change pose not only a challenge to social cohesion and sustainability in rural areas per se, but also to rural research itself.

Over the last 25 years, Czech countryside has been shaped by the coincidence of transformation processes involving democratisation and privatisation dimensions and more general demographic and economic trends - population ageing, metropolisation and globalisation (Čermák, Hampl and Müller 2009). These changes have affected both the functional position of rural areas within a socio-spatial system and the internal differentiation of rural areas. As a result, the significance of rural areas' residential function has increased, and emphasis on the consumption aspects of countryside has grown. A radical population deconcentration trend started to affect the rural

1 Both concepts emerged initially in the US and the UK to point out the specifics of rural poverty and deprivation. 
hinterlands of cities, towns and more distant localities at the end of the 1990s (Ouředníček 2007). In many aspects, the development trends of the past years bear a similarity to the changes described in the UK under the term "rural restructuring" (Marsden et al. 1990; Woods 2004). The proponents of the rural restructuring thesis noticed that globalisation of production, post-industrialisation, declining influence of productivist agriculture, and an influx of middle class in rural areas significantly transformed the power constellations in the countryside and shifted rurality towards postproductivism (Cloke and Goodwin 1992), i.e. decreasing the productivist functions of countryside and increasing its consumption-related significance.

However, all the changes of the Czech countryside are interpreted as a shift towards a multifunctionality of rural areas (McCarthy 2005) rather than as a general trend towards post-productivism; indeed, large parts of Czech rural areas remain based on industrial production.

The aim of the article is to describe the major driving forces of rural development in Czechia over the past 25 years and how they are reflected in the academic discourse. The Czech countryside, in contrast with the dominant picture of East European Countryside (EEC), displays several differences, which have contributed to an overall evaluation of rural development in ECE in the past. In our article, we discuss the nature of 'Czech exceptionalism' in rural development with reference to three examples, namely rural polarisation, land and agriculture and rural policy. We illustrate selected examples with matching empirical figures. We also argue that there is a need to re-examine the use of EEC as a concept framing the position of sociology in rural research. Methodologically speaking, the article is based on secondary analysis of existing data sources and a review of concurrent literature.

\section{Changing rural areas in Czechia}

\section{Rural population turnaround}

Rural areas in Czechia have attracted many people over the past two decades thanks to urban-to-rural migration at all levels (Šimon 2014). The population in Czechia is ageing, as it is in all other countries of Eastern Europe. The mean age of the population has grown by two years in all administrative regions over the last decade (Šimon and Mikešová 2014). However, unlike in many 
ECE regions, there is an overall population growth in Czechia supported by a small in-migration which is exceeding a negligible out-migration. The main source countries of in-migration are Slovakia and Ukraine. Newcomers tend to settle in large urban centres, which is similar to most other countries with significant immigration. In the Czech case, however, it is also increasingly common for non-natives to be found in non-metropolitan areas. These basic geographies are shaped by a direct migration from other countries, although they also result from rapidly evolving secondary migrations within the country (Čermák et al. 2014).

The space where human activities take place has become increasingly important since 1989; many mechanisms of socio-spatial polarisation are working and slowly or quickly changing previous patterns of human activities. The dominant forces shaping population distribution within the country are suburbanisation and metropolisation, which are typical for many other liberal economies (Champion 1989; Fielding 1989). Polarisation increases the gap between peripheral rural areas with an underdeveloped labour market, negative demographic trends, and slow deterioration of living conditions, as well as other rural territories, particularly areas benefiting from suburbanisation and experiencing rapid development. The extent of residential decentralisation is aptly illustrated by a population development chart divided into basic settlement categories (Figure 1). It shows the population growth of a majority of small rural villages and one city - the capital city of Prague. Other cities and towns have also experienced population decreases.

Current migration patterns are described as a metropolitan life-cycle migration model. Young people move to cities, middle-aged people to suburbs, and older people to rural areas (Geyer and Kontuly 1996). Residential decentralisation is not only happening in big cities, but also in smaller cities and towns (see Figure 2). Residential decentralisation is spatially selective, but it also includes rural municipalities beyond metropolitan regions. Even remote rural areas have experienced an increase in total population number. As such, a period of counterurbanisation is documented in Czechia using both quantitative and qualitative data (Šimon 2014). It should be highlighted that this urban-to-rural migration is driven mostly by quality of life and lifestyle motivation, rather than by economic necessity or even subsistence reasons. Counterurbanisation in Czechia is thus similar to the counterurbanisation we know from Western countries (Halfacree 2008; Mitchell 2004). 
Figure 1. Rural population turnaround in Czechia 1995-2013

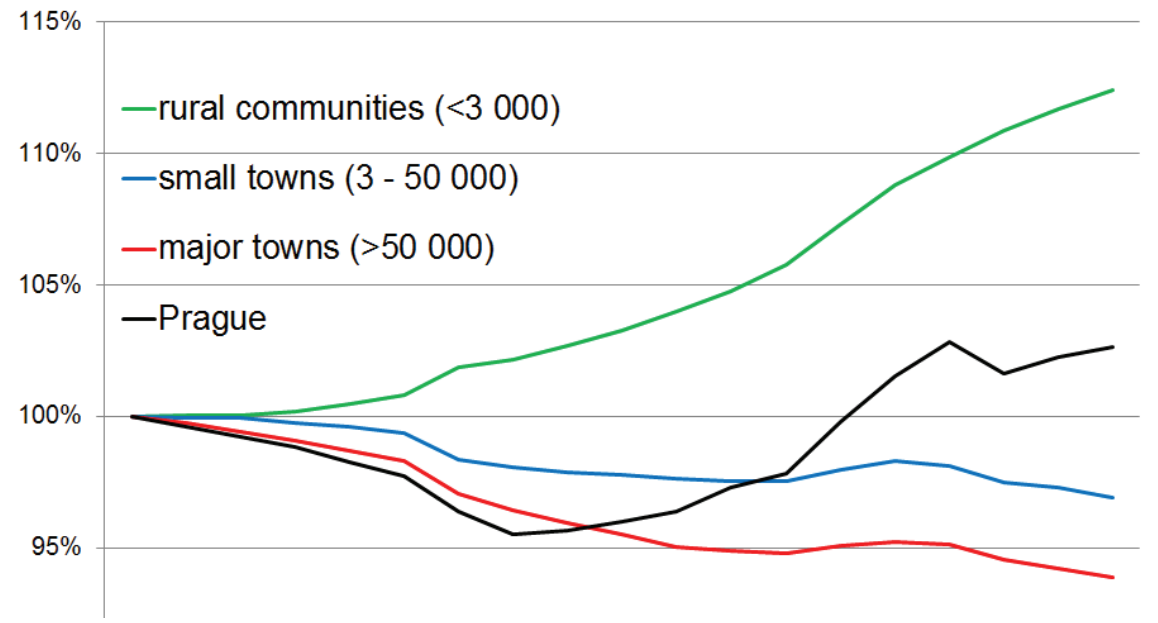

Note: A total population number defines settlement categories in 1995.

Source: Czech Statistical Office, own computations.

Figure 2. Residential decentralisation in Czechia 1995-2013

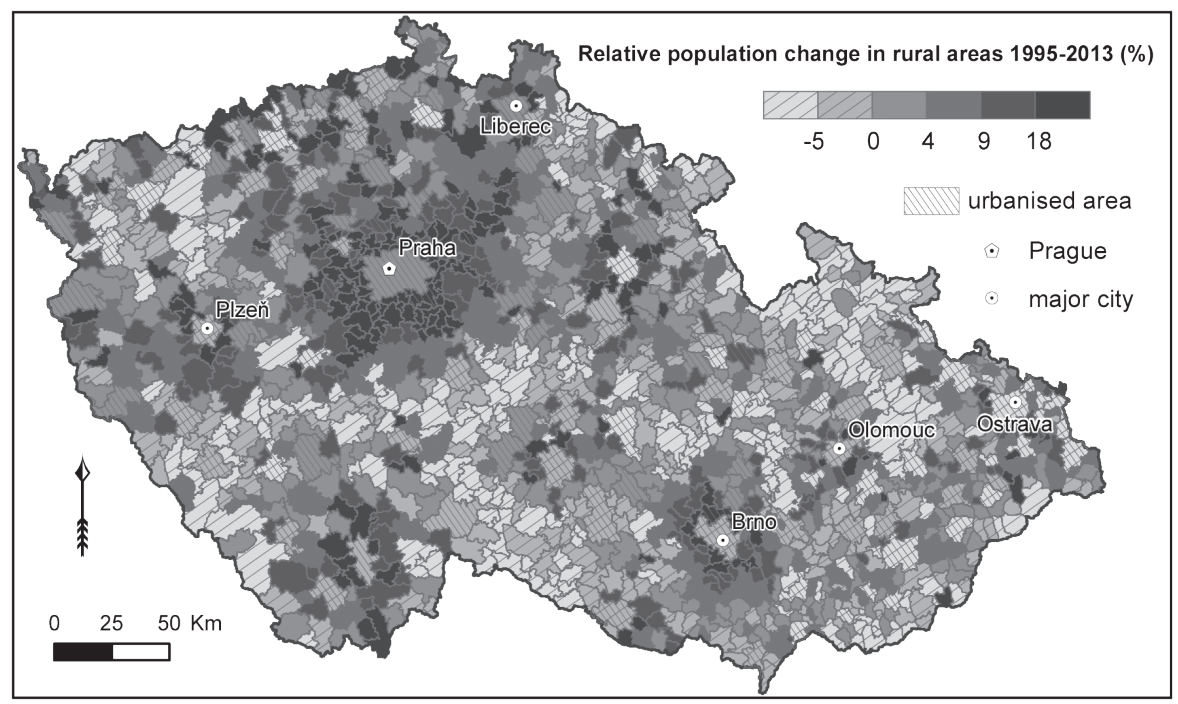

Source: Czech Statistical Office, own computations. 


\section{Rural employment}

The impact of the emerging liberal market economy and the transformation of collectivised agriculture has resulted in different outcomes in ECE countries. Firstly, the privatisation of agricultural enterprises has resulted in an unprecedented fragmentation of agriculture and an emergency situation for many of the very small farms in most countries (Petrick and Weingarten 2004). Secondly, the agricultural sector has partially moderated the social consequences of industrial shutdowns and an agrarisation of rural labour markets has emerged (Banski 2003). Thirdly, the limited profitability and viability of small farms have enhanced the need for an income diversification, partially within a grey economy (Greif 2004). In sum, processes within many rural labour markets in ECE countries have been described as representing a gradual stabilisation of limited regional opportunity structures accompanied by the important role of agriculture.

The post-communist development took a different path in Czechia. The country faced structural economic consequences of communist breakdown which were similar to those of other ECE countries. However, there was a different legacy at the beginning of the transformation, which manifested itself in a high level of urbanisation of the Czech society and a traditionally high industrialisation of rural areas. Before the transformation period, agriculture was the main employment sector in a minority of rural regions. A high level of rural industrialisation was fostered by the state policy of reducing regional disparities and subsidising public transport during the state socialism and almost complete nationalisation and collectivisation of agriculture. More than 500,000 jobs in agriculture offered employment for only $20 \%$ of the rural population at the end of 1980 s. Moreover, a significant portion of formally agricultural employees actually worked in industrial or service-related jobs due to a large farm structure and high activity diversification in agriculture. The end of state agricultural subsidy resulted in a decrease of agricultural production and a sharp decrease of agricultural employment after 1989. Agricultural employment dropped by $25 \%$ in the first three years of transformation and by more than $5 \%$ each following year until 2009 (Figure 3). Interestingly, the EU accession and implementation of CAP did not influence rural employment dynamics in a significant way. The trajectory of high employment in big companies and low employment in small private farms continued further, before stabilising after 2010. 
The transformation of agricultural cooperatives and state farms resulted in a sustainment of the previous large farm structure. New landholders (by restitution) mostly rented their land and only a minority of them decided to establish their own business. A very small group of family farms emerged, and all of these have been quantitatively stable until today. The vast majority of the agricultural population remained employed on large farms (Figure 3). Thus, small and subsistence farming did not have a significant buffer function in terms of the ongoing economic crisis and agrarisation was by no means the preferred escape strategy of the population (Brown and Schafft 2002).

Figure 3: Absolute number of active population employed in agriculture in Czechia, 19932013

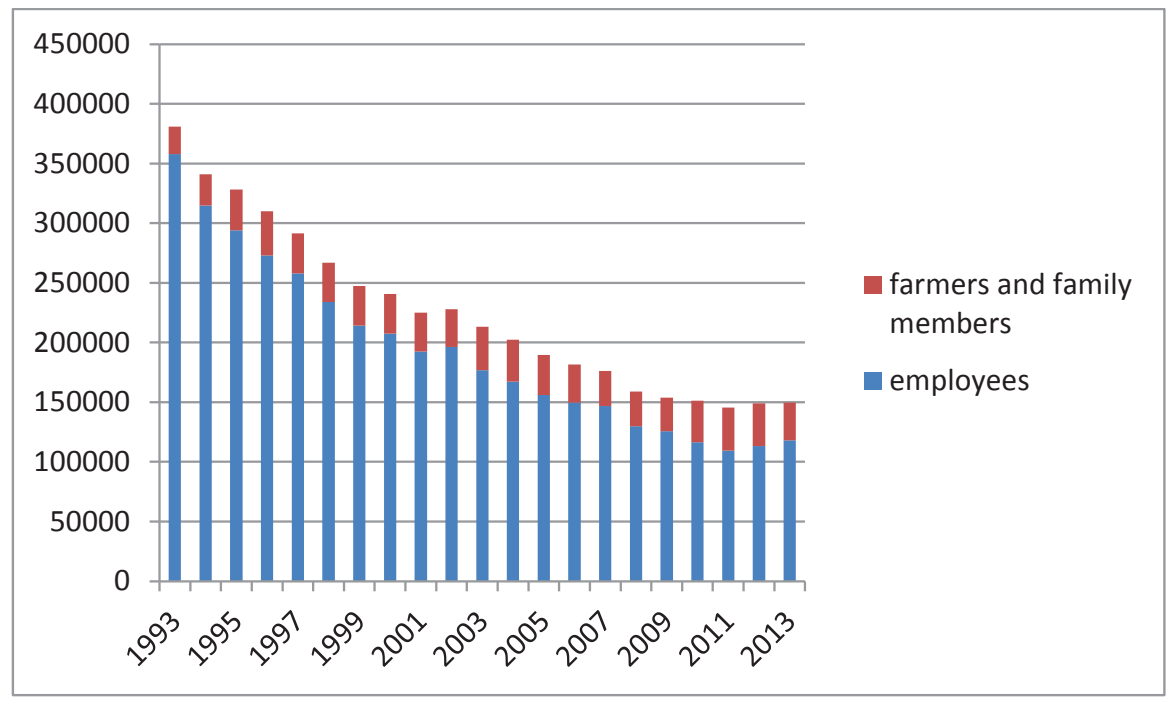

Source: Czech Statistical Office - Labour Force Survey 1993-2013, own computations.

Worried rural sociologists observed agricultural labour shedding in the 1990s and highlighted the risk of rural poverty, the spread of unemployment, and income polarisation (Hudečková and Lošták 1995). However, unlike many other CEE rural regions, most parts of Czech rural areas demonstrated a high resilience and escaped the dangers of social marginalisation as a consequence of successful agricultural transformation. Labour shedding in agriculture did not lead to significant unemployment growth. The dynamics of agricultural unemployment to unemployment in the whole population can be compared 
(Figure 4) based on the Labour force survey (LFS) panel data. Rural unemployment, measured as the share of agriculturally employed people that became unemployed in a successive year, did not exceed the unemployment rate from other economic sectors, neither in the 1990s, nor later. In contrast, the share of the agricultural population who became unemployed was lower than in other sectors for most years (Figure 4). Low rates of agricultural unemployment signal a smooth absorption of the agricultural population into other employment opportunities. As a result, rural regions with initial high intensity of agricultural employment survived the transformation period without social disturbances, and escaped the typical threats faced by CEE rural areas, including agricultural poverty due to fragmentation, inefficiency, and subsistence farming as well as high unemployment levels due to limited opportunity structures outside agriculture (Petrick and Weingarten 2004).

Figure 4. Move into unemployment - agriculturally active versus all economically active

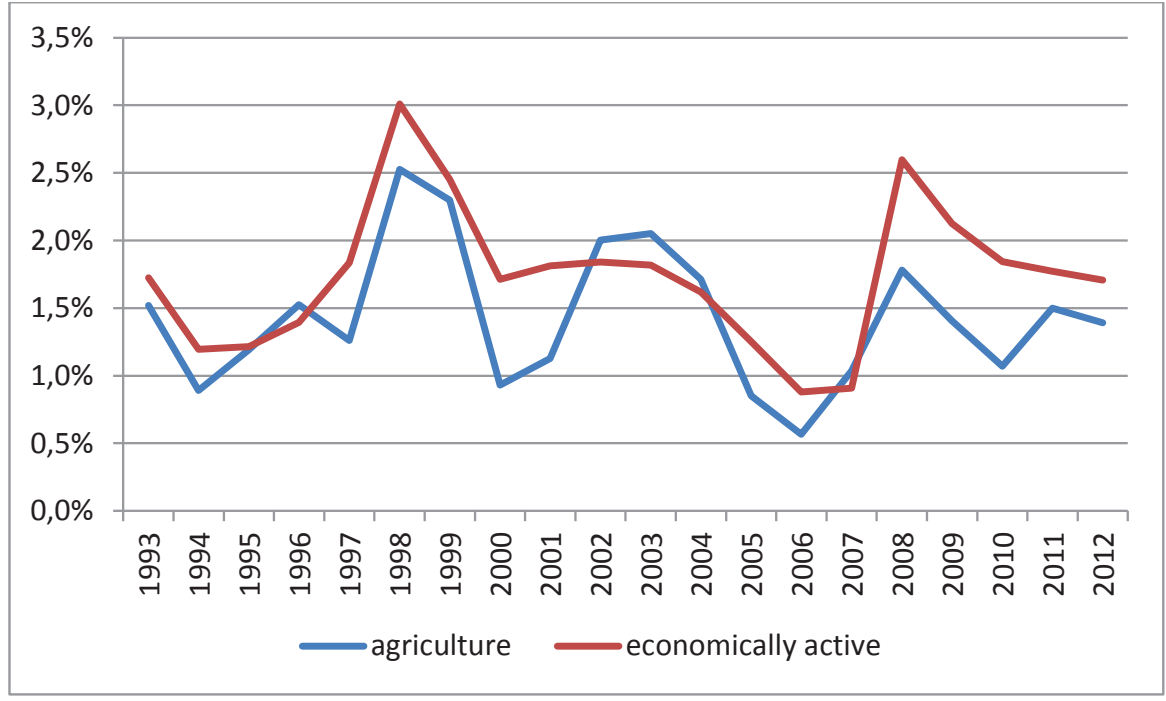

Source: Czech Statistical Office - Labour Force Survey 1993-2013, own computations.

\section{Rural governance}

An unprecedented and internationally incomparable wave of administrative fragmentation occurred in Czech rural areas at the beginning of the 1990s. Put simply, hundreds of municipalities, which were forcefully amalgamated 
during communist times, took advantage of the chance to establish themselves again as self-governing bodies, even though they had a limited population size (Illner 1999). As a result, the median size of Czech municipalities is approximately 380 inhabitants, while $25 \%$ of municipalities have less than 200 inhabitants. Many scholars have asked whether such an extreme municipal fragmentation is sustainable (Hampl and Müller 1998). On one hand hand, we know from classical work by Dahl and Tufte (1973) that small political systems are characterised by low levels of capacity. Thus, the limited size of rural municipalities is perceived as a danger in terms of their capacity to accomplish a wide range of goals. On the other hand, fragmented political systems can develop a range of compensatory mechanisms, which make up for their limited internal capacity (Bernard 2015). Despite the indisputable administrative capacity problems faced by the smallest municipalities, their number is stable and there has been no tendency towards voluntary or forced municipal amalgamation so far.

The smooth functioning of small rural municipalities is enabled by three features of the Czech multi-level political-administrative system. Firstly, municipalities have only limited autonomy in planning issues (e.g. zoning) and are dependent on state administration and agencies. Secondly, small municipalities are not in charge of the implementation of state policies. Thirdly, the introduction of a second-tier of subnational government in 2004 transferred many functions (e.g. social services, secondary education, health system, public transport) to the emerging regional bodies, and thus municipal responsibilities remained rather limited.

Europeanisation and the growing importance of EU funding (projectification) in rural development raised the administrative and management-related complexity of rural governance. Planning and implementation of development projects exceeded the capacity of most small rural municipalities. However, the emergence of a specialised "project class" made it possible to compensate for the municipalities' lack of capacity by transferring project administration to external development agencies (Kovách and Kučerová 2006). The externalisation of project management enhanced the capacity of rural actors, but posed a new risk for democratic legitimacy and the economic stability of municipal budgets.

High municipal fragmentation could prove risky in times of economic and demographic instability. Planning of local public policies could represent an obstacle in administratively scattered municipalities and in regions dealing 
with population shrinkage. The effective transformation of service allocation and infrastructure of general interest provision would significantly increase the bargaining costs of transformation due to administrative fragmentation. Thus far, however, most rural areas in Czechia have facilitated the persistence of a fragmented municipal structure.

Endogenous factors related to economic and community development are increasingly important when it comes to quality of life in rural regions. A fragmented municipal structure has the potential to enhance endogenous rural development through the easy involvement of local community actors in governance structures, although creation and maintenance of regionallevel horizontal and vertical linkages seems to be more complicated. Previous studies have found that location in economically weak regions, limited accessibility and scattered settlement structure are more influential than governance related factors (Bernard and Kostelecký 2010).

\section{Changing rural research and discourse}

The description of rural polarisation, land and agriculture and rural policy as key features of rural change is framed within a context of changing rural research. Table 1 provides a synthetic view of changing rural research and illustrates the shifts of key topics in Czech research across rural areas over the past 25 years. The synthetic view attempts to cover three main areas of rural research in three key periods after 1989. It distinguishes the early transformation period in the 1990s, when the most radical changes occurred; the pre-EU-accession period which was typically related to searches for new meaning and rural function; and the post-EU-accession period, when the development of rural areas was heavily shaped by a CAP on Structural Funds of the EU. The detailed elaboration of a rural discourse before 1989, namely between 1985 and 1999, is provided elsewhere (Pospěch 2014).

Rural discourse was heavily driven by official state policy and was focussed mainly on urban-rural convergence during socialism. Rural areas had to provide agricultural production and develop new functions to keep catching up with urban areas. After 1989, rural discourse had to be re-established and a period of targeted rural renewal, a dismissal of agriculture, and a search for new functions of rural emerged (Pospěch 2014). Rural discourse was shaped by a strange combination of capitalist privatisation and re-appearing romantic ideas of traditional rurality in the early 1990s. For example, a return 
to traditional family farming was expected at that time; it did not occur. In fact, the majority of people who got their land back in the restitution process had no means, skills or willingness to become farmers. Rapid de-agrarisation of rural labour markets started instead of Western-Europe-like formation of a dual farm structure with family farms representing a significant employment sector.

New challenges for rural research emerged in the late 1990s and early 2000s. The growth of unemployment, population decentralisation, and income polarisation indicated a new geography of growth and decline, thus reversing foregoing socialist patterns. Previously dilapidated and underfunded peri-urban areas began to grow and the formerly supported country border regions or heavy industry regions began to decline. The qualitative features of rural areas and bottom-up development approaches were assigned new importance. Agriculture and landscape began to be influenced by EU pre-accession tools and an emerging sustainability agenda. A leap in rural research was also conditioned by a better data availability and GIS tools used for analytical purposes.

The Post-EU-accession period, as the category itself suggests, has been heavily driven by the CAP and Structural Funds agenda. One one hand, EU funds are welcomed as a source of additional income, although on the other they are criticised as an ill-targeted and/or un-effective allocation of money. Merging local and EU agendas also leads to a thematic shift and introduction of post-productivist topics (alternative food networks, self-subsistence, animal welfare, etc.), thus increasing the importance of the food agenda (bio, eco, food safety, GMO, etc.), and placing a stronger focus on endogenous sources of development (new localism, new social movements, etc.). In general, such a thematic change is interpreted as a shift to less-structuralist approaches in rural research. Besides this, we witness a certain absence of traditional topics of rural sociology. As the former key topics and key target groups became less frequent or less significant, Czech rural sociology has yet to find and grasp new elements of the rural. 
Table 1. Changing rural research in Czechia 1989-2015

\begin{tabular}{|c|c|c|c|}
\hline & $\begin{array}{l}\text { Early transformation } \\
\text { in } 1990 \mathrm{~s}\end{array}$ & $\begin{array}{l}\text { Pre-EU-accession } \\
\text { period until } 2005\end{array}$ & $\begin{array}{c}\text { Post-EU-accession period } \\
\text { after } 2005\end{array}$ \\
\hline $\begin{array}{c}\text { Rural } \\
\text { polarisation }\end{array}$ & $\begin{array}{l}\text { - urban-rural polarity } \\
\text { - threat of depopulation } \\
\text { - social cost and } \\
\text { spatial outcomes } \\
\text { of transformation } \\
\text { - negative socialist } \\
\text { legacy } \\
\text { - descriptive studies } \\
\text { of rural population }\end{array}$ & $\begin{array}{l}\text { - residential } \\
\text { decentralisation and } \\
\text { suburbanisation } \\
\text { - rural unemployment } \\
\text { - low residential } \\
\text { mobility } \\
\text { - income polarisation } \\
\text { of rural population }\end{array}$ & $\begin{array}{l}\text { - inner peripheries } \\
\text { - socially excluded localities } \\
\text { - residential decentralisation, } \\
\text { suburbanisation, } \\
\text { counterurbanisation } \\
\text { - population ageing } \\
\text { - amenity migration }\end{array}$ \\
\hline $\begin{array}{l}\text { Land and } \\
\text { agriculture }\end{array}$ & $\begin{array}{l}\text { - privatisation } \\
\text { of agricultural } \\
\text { cooperatives } \\
\text { - land and property } \\
\text { restitution } \\
\text { - rural employment } \\
\text { - decrease } \\
\text { of agricultural } \\
\text { production }\end{array}$ & $\begin{array}{l}\text { - pre-accession tools } \\
\text { - agriculture regulation } \\
\text { and support policies } \\
\text { - bad soil management } \\
\text { and appropriation } \\
\text { of land } \\
\text { - sustainable agriculture }\end{array}$ & $\begin{array}{l}\text { - rural unemployment } \\
\text { - impact of CAP } \\
\text { - food security } \\
\text { - post-productivist } \\
\text { countryside } \\
\text { - non-agricultural functions } \\
\text { of farms }\end{array}$ \\
\hline $\begin{array}{l}\text { Rural } \\
\text { policy }\end{array}$ & $\begin{array}{l}\text { - rural renewal, rural } \\
\text { idyll } \\
\text { - environmental } \\
\text { movements } \\
\text { - ecologisation } \\
\text { - self-governance } \\
\text { in rural areas } \\
\text { and restoration } \\
\text { of democracy } \\
\text { - a lack of state rural } \\
\text { policy }\end{array}$ & $\begin{array}{l}\text { - Europeanisation } \\
\text { of rural } \\
\text { - SAPARD impact } \\
\text { - new roles and } \\
\text { functions of rural } \\
\text { - bottom-up approaches }\end{array}$ & $\begin{array}{l}\text { - CAP of EU } \\
\text { - social capital in rural areas } \\
\text { - rural social movements } \\
\text { - rural multifunctionality } \\
\text { - global countryside }\end{array}$ \\
\hline
\end{tabular}

Source: own elaboration.

\section{Discussion \& Conclusion}

The analysis of 'Czech exceptionalism' in rural development over the past quarter of a century allows us, with a certain caution, to label this period as a rural idyll. Czech rural areas as a whole, as well as the majority of rural regions, experienced overall population growth and even a period of counterurbanisation. Rural areas also displayed a high level of resilience in absorbing a decline of agriculture production and employment through the 1990s, as well as impacts of EU accession in 2004 and related policy 
changes. A highly fragmented structure of municipalities in rural areas proved to be stable and adaptable to changing conditions, even though it had lower levels of capacity than larger local political systems.

The examination of key driving forces of rural change in Czechia over the past 25 years illustrates a path divergence (Martin and Sunley 2006) in rural development in ECE. Although the common socialist past created a "joint development trajectory" of rural areas for many decades, it did not erase high development diversity between both post-communist countries and urban and rural regions within them. Afterwards, a re-emergence of pre-socialist patterns of rural diversification has been further exacerbated by different paths of agricultural transformation, by different geographical opportunities for rural renewal, and by the growing impact of global countryside (Woods, 2007), all of which has led to a rapid polarisation in EEC over the last quarter of a century. Under these conditions we might easily wonder whether the use of the EEC concept still holds as a key framework for sociological research in rural areas today. We argue that there is a need to critically re-examine the use of the EEC concept. We suggest that using this concept solely as a geographical referent - ruralities in EEC differ to an extreme level - might more obscure than elucidate the situation due to a large rural diversification in the region. Therefore, the concept should be used exclusively in cases where it provides an explanatory power to the studied phenomena. Otherwise, there is a risk of misguiding rural research related to EEC countries in general. In our opinion, a debate regarding the EEC concept should foster an effort for a systematic comparative research. There are many joint challenges for rural areas such as demographic ageing or spatial impact of politics of austerity, which deserve broader scholarly attention. In particular, a lack of research focussed on rural poverty from the comparative perspective is highlighted. In general, studies focussed on countryside in EEC should engage more strongly with contemporary social theory and attempt to address wider and emerging debates in rural studies and rural sociology.

\section{References}

Bański, J., 2003. Transforming the functional structure of Poland's rural areas'. Alternatives for European Rural Areas. Warsaw: European Rural Development Network, pp. 19-37. 
Baum, S. \& Weingarten, P., 2002. Developments of rural economies in the Central and Eastern Europe: an overview. Changing Functions of Rural Areas in the Baltic Sea Region. Warsaw: IGSO PAS. pp. 7-31.

Bernard, J. \& Kostelecký, T., 2010. Části obcí s vlastní samosprávou a bez ní: Vliv administrativního statusu části obce na její rozvoj (Parts of Municipalities with Local Governments and without: The Impact of Administrative Status of Parts of Municipalities on their Development). Acta politologica 2(3), pp. 46-61.

Bernard, J., 2015, Demokratie im Dorf - Demokratiequalität in kleinen Schweizer Gemeinden (Democracy in a village - quality of democracy in small Swiss villages). Demokratie in der Gemeinde: Herausforderungen und mögliche Reformen, Zürich: Schulthess, pp. 59-92.

Brown, D. L. \& Schafft, K. A., 2003. Social Exclusion in Rural Areas of Central and Eastern Europe. Eastern European Countryside 9, pp. 27-44.

Brown, D.L. \& Schafft, K.A., 2002. Population deconcentration in Hungary during the post-socialist transformation. Journal of Rural Studies, 18(3), pp. 233-244. Available at: http://dx.doi.org/10.1016/s0743-0167(01)00046-8.

Cloke, P. et al., 1995. Deprivation, poverty and marginalization in rural lifestyles in England and Wales. Journal of Rural Studies, 11(4), pp. 351-365. Available at: http://dx.doi.org/10.1016/0743-0167(95)00016-x.

Čermák, Z., Hampl, M. \& Müller, J., 2009. Současné tendence vývoje obyvatelstva metropolitních areálů v Česku: dochází k významnému obratu? (Contemporary Tendencies of Population Development in Czech Metropolitan Areas) Geografie, 114(1), pp. 37-51.

Dahl, R. A. \& Tufte, E. R., 1973. Size and Democracy, Stanford: Stanford University Press.

Fielding, A. J., 1989. Migration and Urbanization in Western Europe since 1950. The Geographical Journal, 155(1), p. 60. Available at: http://dx.doi. org/10.2307/635381.

Geyer, H. S. \& Kontuly, T. M., eds. 1996. Differential Urbanization: Integrating Spatial Models. London: Arnold.

Greif, F., 2004. Off-Farm Activities and Subsistence Farming in CEE Countries A Statistical Approach. The role of agriculture in Central and Eastern European rural development: engine of change or social buffer? Studies on the agricultural and food sector in Central and Eastern Europe (No. 25), Halle: IAMO, pp. 210219.

Halfacree, K., 2008. To revitalise counterurbanisation research? Recognising an international and fuller picture. Popul. Space Place, 14(6), pp. 479-495. Available at: http://dx.doi.org/10.1002/psp.501.

Hampl, M., \& Müller, J., 1998. Jsou obce v České republice př́iliš malé? (Are municipalities too small in the Czech Republic?). Geografie-Sborník ČGS 103(1), pp. 1-12. 
Hudečková, H. \& Lošták, M., 1995. Social costs of transformation in the Czech agriculture. Eastern European Countryside 2(1), pp. 81-90.

Champion, A. G., ed. (1989): Counterurbanization: The Changing Pace and Nature of Population Deconcentration. Arnold, London, $266 \mathrm{~s}$.

Cloke, P. \& Goodwin, M., 1992. Conceptualizing Countryside Change: From PostFordism to Rural Structured Coherence. Transactions of the Institute of British Geographers, 17(3), p. 321. Available at: http://dx.doi.org/10.2307/622883.

Illner, M., 1999. Territorial Decentralization: An Obstacle to Democratic Reform in Central and Eastern Europe? The Transfers of Power: Decentralization in Central and Eastern Europe, Budapest: The Local Government and Public Service Reform Initiative, pp. 7-42.

Janská, E., Čermák, Z. \& Wright, R., 2013. New Immigrant Destinations in a New Country of Immigration: Settlement Patterns of Non-natives in the Czech Republic. Popul. Space Place, 20(8), pp. 680-693. Available at: http://dx.doi. org/10.1002/psp.1824.

Martin, R. \& Sunley, P., 2006. Path dependence and regional economic evolution. Journal of Economic Geography, 6(4), pp. 395-437. Available at: http://dx.doi. org/10.1093/jeg/lbl012.

McCarthy, J., 2005. Rural geography: multifunctional rural geographies - reactionary or radical? Progress in Human Geography, 29(6), pp. 773-782. Available at: http:// dx.doi.org/10.1191/0309132505ph584pr.

Mitchell, C.J.., 2004. Making sense of counterurbanization. Journal of Rural Studies, 20(1), pp. 15-34. Available at: http://dx.doi.org/10.1016/s0743-0167(03)00031-7.

Ouředníček, M., 2007. Differential Suburban Development in the Prague Urban Region. Geografiska Annaler, Series B: Human Geography, 89(2), pp. 111-126. Available at: http://dx.doi.org/10.1111/j.1468-0467.2007.00243.x.

Petrick, M. \& Weingarten, P., 2004. The role of agriculture in Central and Eastern European rural development: an Overview. The role of agriculture in Central and Eastern European rural development: engine of change or social buffer? Studies on the agricultural and food sector in Central and Eastern Europe (No. 25), Halle: IAMO, pp. 1-21.

Pospěch, P., 2014 Discursive no man's land: Analysing the discourse of the rural in the transitional Czech Republic. Journal of Rural Studies 32(1), pp. 96-107. Available at: http://dx.doi.org/10.1016/j.jrurstud.2014.01.006.

Rey, V., \& Bachvarov, M., 1998. Rural settlements in transition-agricultural and countryside crisis in the Central-Eastern Europe. GeoJournal, 44(4), pp. 345-353.

Swain, N., 2000. The rural transition in post-socialist Central Europe and the Balkans. Halle: Max Planck Institute for Social Anthropology.

Šimon, M. \& Mikešová, R. (Eds), 2014. Population Development and Policy in Shrinking Regions: the Case of Central Europe. Prague: Institute of Sociology, Czech Academy of Sciences. 
Šimon, M., 2014. Exploring Counterurbanisation in a Post-Socialist Context: Case of the Czech Republic. Sociologia Ruralis, 54(2), pp. 117-142. Available at: http:// dx.doi.org/10.1111/j.1467-9523.2012.00576.x.

Tickamyer, A., 1990. Poverty and Opportunity Structure in Rural America. Annual Review of Sociology, 16(1), pp. 67-86. Available at: http://dx.doi.org/10.1146/ annurev.soc.16.1.67.

Woods, M., 2007. Engaging the global countryside: globalization, hybridity and the reconstitution of rural place. Progress in Human Geography, 31(4), pp. 485507. Available at: http://dx.doi.org/10.1177/0309132507079503. 